University of South Florida

DIGITAL COMMONS

Digital Commons @ University of

@ UNIVERSITY OF SOUTH FLORIDA

South Florida

Fall 1963

\title{
The African Mineral Industry: Evolution of a Supranational Level of Integration
}

Alvin W. Wolfe

Washington University, St. Louis, wolfe@cas.usf.edu

Follow this and additional works at: https://digitalcommons.usf.edu/ant_facpub

Part of the Anthropology Commons

\section{Scholar Commons Citation}

Wolfe, Alvin W., "The African Mineral Industry: Evolution of a Supranational Level of Integration" (1963). Anthropology Faculty Publications. 5.

https://digitalcommons.usf.edu/ant_facpub/5

This Article is brought to you for free and open access by the Anthropology at Digital Commons @ University of South Florida. It has been accepted for inclusion in Anthropology Faculty Publications by an authorized administrator of Digital Commons @ University of South Florida. For more information, please contact digitalcommons@usf.edu. 
from: Sacial Problems, Fall 963

\title{
THE AFRICAN MINERAL INDUSTRY: EVOLUTION OF A SUPRANATIONAL LEVEL OF INTEGRATION
}

\author{
ALVIN W. WOLFE \\ Wasbington University
}

The need for some sort of human organization at a level of integration superior to the war-prone nation-state has stimulated rational attempts to invent structures intended to reduce international conflict. These inventions, such as the League of Nations and the United Nations, tend to use the very units that are in contention, nationstates, and the same principles of organization, centralized power in a bureaucratic framework, that characterize the nation-state. The long history of development of human social systems suggests, however, that development from one "level of sociocultural integration," to use the concept of Julian Steward, ${ }^{1}$ to a new, wider level involves the emergence of genuinely different principles which yield qualitatively different groups at the higher level. A tribe is not a federation of families; a nation is not a federation of tribes; neither is it likely that man's present problem will be solved by a federation of states. It may be that the current decades of enormous upheaval, of crumbling political empires, of rapid social change and population growth, and of acceleration of industrialization, will give rise to some new system of social control somewhat independent of the currently troublesome units, the nation-states. The present paper does not purport to describe a utopian system for establishing world peace. It merely calls attention to a developing system with some characteristics that might make effective an international, supranational, integrative system.

In pursuing answers to quite another question, namely, why the "wind of change" expected to sweep southward

1 Julian Steward, Theory of Culture Change. Urbana: University of Illinois Press, 1955. over Africa was fairly halted for a time at the point where minerals become important, I found the mineral extraction industry of southern Africa to be organized in an intricate social system based more on overlapping membership of a variety of groups than on a bureaucratic centralization of administrative power. The network binds groups that are different both structurally and functionally, some business corporations, some states, some families, in a modern supranational structure that is more than just international. The ties among these entities are such that the boundaries of the system are ambiguous. Though operating in a complex modern world, the structure of this system appears to the anthropologist analgous to "acephalous" segmentary social systems. An even better comparison might be with such smaller societies as those of aboriginal Australia where networks of overlapping family, horde, and totemic groups provide a high degree of order without centralized control.

Before proceeding, I should register some reservations. A system such as this is difficult to describe briefly. This preliminary report, based on incom. plete data on a system that is dynamic, continuously adapting to changing conditions, attempts only to point out a few salient features which appear important for the future development of this system, and to point out some of those changing conditions to which this system seems adaptable.

\section{SOME PATTERNS OF INTEGRATION IN THE MINING INDUSTRY}

The several hundred mining companies operating in southern Africa are integrated through a series of relationships that focus on some of the larger among them-this system I have elsewhere called the Cape-to-Katanga 
Miners. ${ }^{2}$ Then, in a variety of ways, these corporations are linked with governments.

The most direct connections are those of parent companies to whollyowned subsidiaries. Thus The Anglo American Corporation of South Africa is sole parent to Lydenburg Estates, New Era Consolidated, South African Mines Selection, Anglo American Rhodesian Services, and Anmercosa Land and Estates. ${ }^{3}$ Johannesburg Consolidated Investment Company is parent to African Asbestos-Cement Corporation, Barnato Brothers, Barnato Holdings, and others. Such relationship systems based on complete ownership are, of course, limited in scale in the same way as kinship groups based on filiation alone are limited.

The relationships that give this system much wider span involve the sharing of interest in operating firms. Just as marriages in many social systems establish affinal ties between two otherwise separate, perhaps opposing, lineages, common financial interests establish a network of relations between otherwise distinct corporations. This network is partially expressed in interlocking directorates, for any business group attempts to have its own representatives on the board of directors of another company in which it holds stock or has some other direct interest.

The extent to which this principle operates can be readily observed from the lists of directors of nine companies chosen as key companies from among the several hundred for which such information is available because they, with their subsidiaries and associated firms, can be seen as dominating the

2 Alvin W. Wolfe, "The Team Rules Mining in Southern Africa," Toward Freedom, January, 1962.

3 Unless other references are given, all particulars on companies are taken from (1) Mining Year Book, London: Walter E. Skinner; (2) Moody's Banking and Finance Manual: (3) Moody's Industrials Manual; or (4) Poor's Register. exploitation of all the mineral resources of southern Africa. These "key" companies are: Union Minière du Haut Katanga, Tanganyika Concessions, British South Africa Company, Anglo American Corporation of South Africa, De Beers Consolidated Mines, Johannesburg Consolidated Investment Company, Rhokana Corporation, Mufulira Copper Mines, and Rhodesian Selection Trust. (See Chart 1.) Eighty-eight men occupy the $130 \mathrm{di}$ rectorships; still closer to the hub, six men occupy twenty-two seats. Analysis of the relationships of these, and many other related corporations, suggests that the interlocking may follow a regular pattern: roughly, the units which are most similar in function and therefore most prone to compete have the high est degree of interlocking. Those that are functionally disparate can rely more on the market principle in their relations, while the similar companies must create the conditions for cooperation on the basis of reciprocity. Thus, Rhokana and Rhodesian Selection Trust are alike in their emphasis on mining copper in the Copperbelt, but they avoid the temptation to compete by interlocking heavily through a third company, Mufulira Copper Mines, whose sixteen man board is nearly filled by nine directors of Rhodesian Selection Trust and six directors of Rhokana. On the other hand, the British South Africa Company, whose place in the system is functionally unique in that it does not operate mines but "owns" the mineral resources over vast parts of the territory including the Copperbelt, needs only three joint directors with Anglo American Corporation of South Africa and only one with Tanganyika Concessions. It may, however, be significant that the three of them-BSA, Anglo-American, and T.C.- together own the Rhodesian Iron and Steel Corporation (RISCO) of Southern Rhodesia. Tanganyika Concessions, itself, has another functionally distinct position in that it 


\section{CHART}

\section{Interlocking Directorates at the Hub of the Mineral Industry of SOUTHERn Africa*}

\begin{tabular}{|c|c|c|c|c|c|c|c|c|c|c|}
\hline \multirow{3}{*}{ 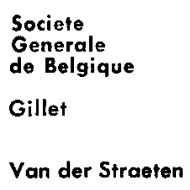 } & \multirow{3}{*}{ 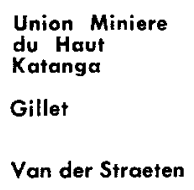 } & \multirow{2}{*}{$\begin{array}{l}\text { TANGANYIKA } \\
\text { Concessions } \\
\text { Oppenheimer, } \\
\text { H. }\end{array}$} & \multirow{2}{*}{$\begin{array}{l}\text { British South } \\
\text { Africa } \\
\text { Company } \\
\text { Oppenheimer, } \\
\text { H. }\end{array}$} & \multirow{2}{*}{$\begin{array}{l}\text { Anglo } \\
\text { American } \\
\text { Corp. of S. A. } \\
\text { Oppenheimer, } \\
\text { H. }\end{array}$} & & \multirow[t]{2}{*}{$\begin{array}{l}\text { Johannesburg } \\
\text { Cons. Invest. }\end{array}$} & \multirow{2}{*}{$\begin{array}{l}\text { Rhokana } \\
\text { Corporation } \\
\text { Oppenheimer, } \\
\text { H. }\end{array}$} & \multirow{2}{*}{$\begin{array}{l}\text { Mufulira } \\
\text { Copper Mines } \\
\text { Oppenheimer, } \\
\text { H. }\end{array}$} & \multirow{2}{*}{$\begin{array}{l}\begin{array}{l}\text { Rhodesian } \\
\text { Shelection } \\
\text { Trust }\end{array} \\
\text { Hochschild, W. }\end{array}$} & \multirow{2}{*}{$\begin{array}{l}\text { American Metal } \\
\text { Climax, Inc. } \\
\text { Hochschild, W. }\end{array}$} \\
\hline & & & & & & & & & & \\
\hline & & Van der Straeten & Wilsọn, A. & Wilson, A. & Wilson, A. & Blair & Rowlandson & Hochschild, H. & Hochschild, H. & Hochschild, H. \\
\hline Deviller & Waterhouse & Waterhouse & Acutt & Acutt & Watson & Watson & Seys & Bradford & Bradford & Bradford \\
\hline Bonvoisin & Selborne & Selborne & Annan & Clark & Clark & & Clark & Clark & Moore & Dean \\
\hline \multirow[t]{3}{*}{ Robiliart } & & Robiliart & Emrys-Evans & Emrys-Evans & Joel & Joel & Newson & Newson & Coolbaugh & Coolbaugh \\
\hline & & Guillaume & $d^{\prime}$ Erlanger & Hagart & Hagart & Hagart & Taylor & Taylor & Finn & Childs \\
\hline & & de Spirlet & Berry & Wilson, W. & & & Wilson, W. & Goudie & Goudie & Goudie \\
\hline Marthoz & Marthox & Hudson & Grenfell & $\begin{array}{l}\text { Oppenheimer, } \\
\text { P. }\end{array}$ & $\begin{array}{l}\text { Oppentheimer, } \\
\text { P. }\end{array}$ & Findlay & & Lascelles & Lascelles & Bunker \\
\hline De Merre & Paulus & Hutchison & Malvern & Albu & Compton & Richardson & Richardson & Richardson & Irwin & Irwin \\
\hline Wallef & Wallef & Strachan & Hambro & Coulter & Rudd & Frost & & & & Burden \\
\hline Smits & Blaise & Cochran & Robson & Beckingham & & & Beckingham & & & Mudd \\
\hline Nokin & Terwagne & Dickinson & Crawford & Brownrigg & & & Brownrigg & & & Reed \\
\hline Lampert & Alexander & Alexander & & & Forsyth & Harrison & & & & de Neufville \\
\hline \multirow[t]{7}{*}{ Renders } & Sengier & Pinto Basto & & & MeHardy & Kissane & & & & Loeb \\
\hline & Cousin & Turner & & & Leeper & Thomas & & & & MacGregor \\
\hline & Gorlia & & & & de Villiers & Christie & & & & Searls \\
\hline & & & & & Crokaert & Harris & & & & Szold \\
\hline & & & & & Rothschild & Egeland & & & & Thompson \\
\hline & & & & & & & & & & Vuillequez \\
\hline & & & & & & & & & & Beatty \\
\hline
\end{tabular}

*Data as of 1962. 
owns, in addition to much of Union Minière du Haut Katanga, the Benguela Railway, in collaboration with the Portuguese government.

In the American economy, we may need to be reminded, interlocking of directorates is greatest among functionally different corporations (except, of course, in the parent-subsidiary relationship). That the pattern tends to be the opposite in this international, or supranational, system may be important enough to be re-emphasized. Between firms that are functionally distinct there already exists something like organic solidarity, what economic anthropologists would call integration according to the market principle. Between those that do not need each other instrumentally, integration based on the principle of reciprocity is developed by the mechanism of interlocking directorates.

\section{INVOLVEMENT OF STATES IN THE SuPRANATIONAL SYSTEM}

The companies forming the core of this supranational industrial system have usually been referred to as "private" companies and their economic activity attributed to the "private sector" as opposed to the "public sector" of the various "national economies" in which they function. It is important, however, to analyze carefully the statuses and roles of states in a "supranational" system such as we are describing. American scholars, especially, may need to be cautioned not to expect all business and government relations to follow the American ideal of "separation." In southern Africa, at least, states and business corporations have long been closely interwoven, sometimes identical-as in the case of King Leopold's International Association of the Congo which was a private business until the United States Government recognized it as "a friendly power," opening the way to its reconstitution as the Congo

\section{Independent State in 1885.4}

The Congo government, under Leopold and then under the Belgians, owned significant holdings in the "private sector," in companies like Union Minière, Forminière, Géomines, and others. In fact, over the years, income from direct business investments accounted for something like $7 \%$ of total government receipts. ${ }^{5}$ As any other stockholder, the Government under the Belgians could vote its shares in the election of directors and other crucial corporate matters. We shall look more specifically at the Congo situation later, when consideration is given to the effects on this supranational system of the break-up of political empires.

Another state which participates in the Cape-to-Katanga team is Portugal. The government of the Province of Angola holds 200,000 shares in the Companhia de Diamante de Angola (Diamang), which has monopoly rights to diamond deposits. On the board of this company are $H$. J. Joel of De Beers, H. F. Oppenheimer of Anglo American, Baron Bonvoisin of the Société Générale de Belgique, Comte M. de Fernig of the Société Minière du Bécéka (significant in that it is the largest single diamond-producer in the world, located in the Congo). All diamonds produced by Diamang are distributed through The Diamond Corporation, a De Beers subsidiary that administers the cartel arrangements. Aside from the regular benefits the Portuguese government of Angola derives by $50 \%$ participation in profits of the company, the Diamang

4 Anthony S. Reyner, The Republic of the Congo, Development of its International Boundaries (African Reprint Series, No. 9). Institute of African Affairs, Duquesne University, 1961).

$5 \mathrm{~J}$. Wertz, in Organisation financiere du Congo Belge et du Ruana-Urundi, Extrait de L'Encyclopedie du Congo Belge, Bruxelles, 1953; and Banque Centrale du Congo Belge et du Ruanda-Urundi, Rapport, 1959, Bruxelles, 1960. 
board was involved enough in political affairs to loan the government \$3,500,000 in 1955 at $1 \%$ interest.

The Portuguese government is partner to another important firm of the Cape-to-Katanga System operating in Angola. Tanganyika Concessions Limited shares with the government of Angola control of the Benguela Railway, the most efficient route to the Atlantic

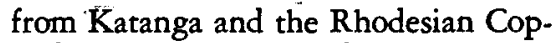
perbelt. Since Tanganyika Concessions is, with the Société Générale de Belgique, an important shareholder in Union Minière, it is clear that they have an interest in how Angola is governed.

The governments of the Rhodesias were, in their beginnings, purely "private" business, namely The British South Africa Company. Those ties are by no means all dissolved. In Northern Rhodesia the mineral rights are still held by that company, which grants concessions to operating companies such as Rhodesian Selection Trust, Mufulira, Nchanga, and many others, each with its nexus to the supranational system. The company, or the Capeto-Katanga Supranational System, more than the government, controls the exploitation of minerals in Northern Rhodesia.

In Southern Rhodesia, matters are different. There the mineral rights were purchased by the government, a "white" government, from the British South Africa Company in 1933, so that the government, not the company, grants concessions and receives royalties. It is not irrelevant to note that Africans are not likely to win political power here, in "Zimbabwe," with anything like the ease with which the transfer took place in Zambia (Northern Rhodesia) or Malawi (Nyasaland) where direct control of minerals was not involved.

The now-defunct government of the Federation of Rhodesia and Nyasaland was a major participant in the mining industry, through its control of the
Rhodesia Railways and the Kariba hydroelectric power system. The British South Africa Company holds the Rhodesia Railways bonds, issued at the time of its nationalization immediately after World War II. The Railways, as a government agency, financed renovation and expansion by borrowing in the United States and from the International Bank. The Kariba Project, too, was financed heavily by the International Bank, in which the American government is the major participant. ${ }^{6}$

The role of the government of South Africa in the supranational system we call the Cape-to-Katanga Miners is enormous, but at the same time so complicated by other political dimensions as to demand much more discussion than can be undertaken here. Minerals made South Africa, minerals maintain South Africa, and South Africa is the axle on which fits the hub of the mineral industry of all southern Africa. Almost half of all the companies directly involved in the Cape-to-Katanga mineral industry are registered in South Africa. Despite that government's unsavory record relative to freedom of persons, it acquired a fine reputation among capital investors, inspiring American businessmen to speak publicly in glowing terms of the possibilities for investment. ${ }^{7}$ The American Export-Import Bank loaned $\$ 127,000,000$ to a

${ }^{6}$ Loans to Rhodesia Railways and the Kariba power project are discussed in several issues of The Annual Report of the International Bank for Reconstruction and Development, especially the Eleventh (1955-56, p. 40) and the Thirteenth (1957-58, pp. 24-25). In addition, Andrew Kamarck reports, "The United States government has put $\$ 56$ million into Rhodesia to help develop copper and cobalt mining and to improve road and railway transport" (p. 130, The United States and Africa, The American Assembly, New York, 1958).

7 See, for example, "The Pied Piper of Inland Steel," Africa Today, March, 1963; see also the South African government's publication South African Scope, wherein American statements are frequently cited. 
number of South African gold mining companies at the rate of $4 \%$ interest in the 1950's. ${ }^{8}$ The U. S. Atomic Energy Commission, which guaranteed the loans, reported the development in the following terms in its report published in 1953: "Over a period of years, the South African government and mining industry, in cooperation with the United States and the United Kingdom, have laid the groundwork for an entirely new industry which recovers uranium as a by-product from the gold ores of Witwatersrand."9 The report fails to note that in addition to laying "the groundwork," the governments also supplied the capital and absorbed the risk by guaranteeing to buy the product at a price fixed to permit amortization and "reasonable" profit. Participation of governments, including that of South Africa, in the mineral industry is clear, and this is our only interest at this point.

A state, of course, has considerable bargaining power vis a vis other social units, such as corporations, operating within their territories. The government of a state, after all, has the "legitimate" right to use force. When it occurs that the force of the state depends heavily on monies that come predominantly from one corporation or a systematically organized group of corporations, it is the government which may be regulated. Governments in Africa are weak in just this way.

The government of The Republic of South Africa is certainly the strongest government in the area of our concern. It is strong, however-and therefore can effectively oppress $8,000,000$

8 Export-Import Bank, Report to Congress, annually.

9 Atomic Energy Commission, Thirteenth Semiannual Report. Washington: U. S. Printing Office, January, 1953, p. 7.

${ }_{10}$ See also AEC Twenty-third Semiunnual Report, 1958, p. 450; also Hearings before the Joint Committee on Atomic Energy, Eighty-fifth Congress of the United States, 1958, pp. 20-21 and passim.
Africans and some thousands of whites who are opposed to it-because it has the financial and diplomatic resources of the vast mineral industry. I add "diplomatic resources" advisedly, since these great corporations, organized supranationally, exert strong though subtle influences-as a case in point, the American governmental loans to Anglo American subsidiaries at $4 \%$ interest at the same time as Anglo American was loaning to its own affiliates at $61 / 2 \%$, and at the same time as a related company, Diamang, loaned to Portugal at $1 \%$. This kind of diplomacy shores up the South African state, as well as the Portuguese state, as well as the Cape-to-Katanga Miners.

Those who see only the enormous growth of state power in the modern world apparently do not take into account the large number of weak states now existing, and the difficulties states encounter in attempting to form stronger units by federation. States cannot readily form overlapping systems among themselves. They can and, as we have seen, do overlap with supranational corporations.

\section{BOUNDARIES OF THE SUPRANATIONAL SYSTEM}

Defining the boundaries of the behavioral system we are here attempting to analyze entails difficulties similar to those met in defining effective political boundaries for societies without state structures-the Nuer of Sudan, the Tallensi of Ghana, or the aboriginal Australians, for example. In the mining industry, as in some small societies, controlled cooperation simply becomes weaker as one moves from the point of focus outward. Familiar with such systems, anthropologists are not likely to conclude that systematic organization is not present where boundaries are ambiguous. Rather, this can be seen as a characteristic of the system-and may even prove of adaptive value in that it permits expansion when the conditions are right and tends to pre- 
serve the center, and thus the system itself, when conditions are adverse.

The nine corporations taken as the focus of the southern African mining industry derive their importance from their relationships with the several hundred other corporations and states operating in the area and then, further, with producers and processors of minerals in other areas of the world. It is impossible here to list all these relationships, but some indication of the way in which they move toward infinity can be given. Union Minière in Katanga is now effectively controlled by the Société Générale de Belgique. The Société Générale shares with De Beers, Anglo American Corporation of South Africa, and the Portuguese state, control of the Diamond Company of Angola. But most of the activity of Société Générale is in Europe, where it links with some of the largest industrial and financial groups in the world. ${ }^{11}$ One of the numerous lines that could be followed leads through a subsidiary, Société Générale des Minerais, with ties connecting it to Amalgamated Metal Corporation in the United Kingdom. Société Générale des Minerais, together with its parent, created a company in Canada, Sogemines Limited, among whose interests are significant holdings in Rio Tinto Mining Company of Canada, a subsidiary of Rio Tinto Co. Limited, part of the Rothschild group in the United Kingdom. Rio Tinto, according to the Mining Yearbook, "has interests in Northern Rhodesia of which the most important is its large holding of shares in Rhokana Corporation Limited. ..." It also has interests in South African mines. Tracing the interconnections among the groups involved in the mineral field reveals circles in cir-

11 For more complete particulars on the extensions of Société Générale, the reader is advised to see Morpbologie des Groupes Financiers, Brussels: Centre de Rocherche et d'Information Socio-Politiques, 1962. cles and circles intersecting circles, so that one cannot say, at any point, this is where the system ends, all these are in, all those are out.

\section{"Acephalous" Character of THE SYSTEM}

Despite the evidence of an orderly system, the mineral industry of southern Africa cannot be said to be under the willful control of a few men at the apex of a bureaucratic hierarchy. In other words, it is not run by a few "evil-minded malefactors of great wealth." Certainly, differences in power are present between corporations and between men, but there is no evidence, even in the more formally organized segment of the system known as the diamond cartel, that one man or one company controls directly the actions of others. Though here much research remains to be done, the cooperation among the units in the system appears dependent on shared interests and shared information throughout the intricate network. Copper production in 1961 was ostensibly geared down in the Copperbelt region in order to conform to the world market, even though the copper industry has no formal control agency comparable to that provided by the Diamond Corporation for the diamond industry. Concerning the use of the several rail routes to the sea, attempts are made to satisfy the various states and corporations involved although there is no "ministry of transportation" to order such cooperation.

Granted that our information on the lines of authority within the structure is at this point scanty, it appears certain there is no single ruler, private or public. Yet this "tribe" pursues its goals with enough efficiency to continue to profit and expand. A positive advantage of this acephalous character is that any sort of a coup d' etat is impossible, as is destruction of the whole system by disintegration of the executive institution. 


\section{Evolutionary Processes}

From this altogether too brief exposition of some structural aspects of the system of mineral exploitation let us turn to view the matter in evolutionary perspective. Three on-going processes tend to foster the development of the system: First, the process of industrialization, pursuing man in every part of the earth, will continuously enlarge the already great demand for minerals. Second, the continuing process of political decolonization enhances the freedom of action of this essentially private system. Third, the lowering of state-imposed barriers to trade leaves the arena freer for the action of supranational economic organizations.

The rapid development of industrial systems in the twentieth century introduces important new factors into the ecological system within which man operates. The idea that increasing productivity is desirable has spread wherever men are. Once on the road toward higher productivity through industrialization there appears no turning back, no levelling off, without disaster. An important meaning of this is seldom recognized. In twentieth century ecological systems, minerals have become as necessary to the main. tenance of human industrial systems as food is to human biological systems.

Without losing sight of the fact that all mankind is becoming involved in industrial systems, let us focus for a moment on one small segment of the species, the men in Europe. A fully industrialized society seems compelled to expand its economy. We may argue whether gross national product must grow at $2 \%, 5 \%$ or $10 \%$, but we agree it must grow. All predictions for western Europe are for growth. Dewhurst and his associates, in a significant volume entitled Europe's Needs and Resources, foresee a $150 \%$ increase in the European GNP by 1970, over the 1957 level. Another study, Britain and Europe, by The
Economist Intelligence Unit Limited, reaches similar conclusions for 1970, but adds that, with free trade, the growth rate should become gradually steeper after that. ${ }^{12}$ The optimism appears typical of economic analyses.

The projected growth in Europe will not be distributed evenly over all sectors of the economy, but will occur strongly in the area of modern metallurgical processing. Europe has done well in the past by processing imported primary products, and further progress in the same direction is expected. "From the standpoint of minerals, metals, and metalworking production, the future is no more than an extension of the past." 13

How does all this affect the mineral. exploiting system of southern Africa? Such growth in Europe should effect major changes in the demand schedule for ferroalloys and nonferrous metals. By 1970, just around the corner, consumption in Europe alone of the major ferroalloys "can reasonably be expected to double the 1955 level." The bulk of Europe's doubled need for ferroalloys will be expected to come from Africa. Africa has almost $25 \%$ of the world supply of manganese, while Europe has 1\%. Africa contains almost $20 \%$ of the world supply of chromite, while western Europe has $1 \%$. Africa has $60 \%$ of the world's cobalt while western Europe has $10 \%$.

Europe's trade in nonferrous metals will double between 1955 and 1970, according to projections, and the growing need will have to be met from African resources. ${ }^{14}$ Copper consumption will double, and it is expected that Katanga and the Copperbelt will remain the principal source of supply.

12 J. Frederick Dewhurst, et al., Europe's Needs and Resources, Twentieth Century Fund, New York, 1957; Britain and Europe, The Economist Intelligence Unit Limited, London, 1957.

13 Dewhurst, op. cit.

14 Britain and Europe, p. 78. 
Zinc consumption will probably be one-and-a-half times the 1957 level by 1970 , and Katanga is the major source. Tin, still indispensable for a number of uses, is concentrated in Africa, probably as much as $50 \%$ of the "Free World" supply. Cadmium has come largely from the Katanga-Rhodesia area.

Add to this projection for Europe the increased need for the same minerals resulting from the growth of industrial systems all over the world, and the dimensions of the ecological problem can be appreciated.

To the degree that minerals will be relatively more important in the years to come, those who control them, or rather the systems involving their control, will have enhanced influence in what we now call international affairs. Representatives of political states may well become less influential than representatives of such functionally necessary supranational systems as the "Cape-to-Katanga Miners."

Although European state power obviously made possible the establishment of such control over mineral resources as is exercised in southern Africa, the current disintegration of colonial empires serves more to strengthen than to weaken the "private" sector of the system. National state controls have frequently been used to inhibit development of widerscale economic integration, since each corporation operates under a charter from one or another nation-state. Dissolution of colonial ties strengthens the position, relative to states, of corporations whose operations are sufficiently internationalized.

The Congo provides a clear case, almost too extreme to use as a general example, of weakening of state power relative to private "international" corporations. By virtue of its colonial charter, the Belgian-administered government of the Congo had almost complete control over the economic destiny of that richly endowed land and a tremendous influence on the rest of the world. The government was in business, and business was good for the seventy years that Belgians manned governmental posts. What was handed over to the Congolese on June 30, 1960 , however, was a meager skeleton of administrative structure stripped of its muscle and therefore heavily dependent on European businessmen members of the supranational mining network.

The key to the Congo situation is the charter company, Katanga Special Committee, in which the government had the right to appoint four of six directors. Among its many holdings was Union Minière, the importance of which is indicated by the fact that it produced annually for the Congo public treasury an amount nearly equal to half the annual budget. The dividends, royalties, and taxes of other mining companies in similar relation to the state must also be considered, but of these the contribution of Union Minière is the largest. The Katanga Special Committee owned 663,000 voting shares of Union Minière, while minority shareholders were Tanganyika Concessions with 375,000 shares and the Société Générale de Belgique with 129,000 shares. ${ }^{15}$

Instead of appointing, through the medium of the Special Committee, directors of Union Minière who would put public interest foremost, the government always named men representing the minority interests, especially the Société Générale de Belgique. Reciprocally, retiring government officials were given berths on subsidiary corporations. In 1960, with the wind of change bringing independence to the

15 Pierre Joye and Rosine Lewin, Les Trusts au Congo, Société Populaire d'Editions, Brussels, 1961, pp. 290-294. Slightly different figures are found in Morpbologie des Groupes Financiers, Centre de Recherche et d'Information Socio-Politiques, Brussels, 1962 , p. 153 , but the proportions are approximately the same. 
Congo, one might have predicted that an African government would remedy the situation in the public favor. The independent Congolese government was never given the opportunity to make such appointments, however, for only days before the Lumumba government was sworn in the Katanga Special Committee was dissolved, or rendered inoperative. The initiative was apparently taken by the Katanga Company, controlled by the Societé Générale de Belgique, when they requested of the government that their one-third holding in the Special Committee be granted them in shares and in real property. According to a study by the Centre de Recherche et d'Information Socio-Politiques this request was made on June 24, 1960, and according to a study by Pierre Joye and Rosine Lewin, the Belgian colonial government accepted the arrangement on June 27, 1960 , just three days before independence. ${ }^{16}$ The result was quite simple: the new Congo government was deprived of a right that had resided, unused, in the Congo state structure for sixty years. Control of Union Minière, and the other enterprises involved, was retained in white European hands. With the return of one-third of the Special Committee's shares to the Katanga Company, members of the Capeto-Katanga team hold a majority of 607,000 shares and can effectively prohibit any influence from the minority holding of 478,000 "public" shares.

As a matter of fact, because the administration of these companies remained entirely under the control of Europeans and because financial transactions take place in Europe and not in the Congo, it was even possible for them to withhold from the Congo government the revenues due it in dividends, royalties, and taxes. Against the argument that Union Minière was being forced by Tshombe to pay these to his regime there is the fact that all

16 Joye and Lewin, op. cit. this started long before Tshombe showed any signs of seceding and certainly before he acquired the power to force anyone to do anything. Whatever the case there, the situation demonstrates a strengthening of the power position of the essentially private system of mineral exploitation by a deliberate weakening of public governmental bodies. The Congo government of 1963 dare not tamper with the mineral rights that, once public, are now somehow "owned" by the Cape-toKatanga team, because the Congo government is financially dependent on these large corporations, and on the U. S., the U. N., and Belgium. These are the Congo's only available sources for capital and technical assistance necessary to further economic development. ${ }^{17}$

It is important to note that not only was the African government weakened, but the Belgian government, too, was affected by "decolonization." With its control of the Special Committee of the Katanga, and by virtue of its sovereignty over the Congo government which possessed significant shareholdings in other mining concerns, the Belgian state had considerable leverage it could apply toward controlling such corporate giants as the Société Générale at home. The dissolution of this Special Committee just before Congolese independence, then, resulted not only in stripping the new Congolese state of much of its potential to influence the mining industry but also in diminution of the Belgian state in this regard.

We have already referred to some aspects of the relations between state and private business in the Rhodesias. The effects of dissolution of the Fed-

${ }^{17}$ A much fuller discussion of the Congo's problems will be found in the author's "The Congo: Economics, Possibility for Viability" to be published in The Proceedings of the Conference on Southern Africa by The American Society of African Culture. 
eration and the granting of political independence to Zambia and Malawi are in the direction also of weakening state power relative to supranationally organized "private enterprise." None will doubt, I presume, that the United Kingdom, in giving up political control over these territories, is a weaker state in that it loses any legal right to regulate matters there. But how about the power of the new state of Zambia (Northern Rhodesia)?

Zambia, like the Congo and every other African state, has as a primary goal economic growth. It must, then, attract capital from capital-exporting countries and it must foster capital formation from profits of its established firms. Minerals are the prime source of wealth, and the mineral rights are held by the British South Africa Company. It is that stalwart of the supranational system that grants concessions to new firms. Should the Zambian government consider nationalization of the mineral rights, a number of consequences would ensue. Under present world conditions, western capital sources both private and public would dry up, unless the state paid heavily for these rights. Second, the United Kingdom would apparently take some action, for Her Majesty's Government in 1962, according to the late Lord Robins, assured the company that it would be in a position to protect the company's mineral rights for another twenty-four years regardless of constitutional developments. ${ }^{18}$ Certain-

18 Federation of Rbodesia and Nyasaland Newsletter, Federal Information Department, Salisbury, March 30, 1962, p. 3: "The President of the British South Africa Company, Lord Robins, said on March 22 he had been assured that the British Government would be in a position to protect his company's Northern Rhodesian mineral rights under the territory's new constitution. Addressing the company's annual meeting in London, Lord Robins said the British South Africa Company would conitinue to own the mineral rights in Northern Rhodesia for a further 24 years." ly, the government of Zambia, alone, is no match for the B.S.A. with or without the support of the United Kingdom.

The government of the Federation was, as we have seen, a fairly influential government, with control of the Railways and the Kariba Project, with a sizeable army and more diversified sources of revenue than any of its constituent territories alone. But with that state (the Federation) dissolved, that particular public power is gone completely. Up to May, 1963 , the only hint of the disposition of those two important public units, the Rhodesia Railways and the Kariba Power Project, is the statement by Minister Kaunda of Zambia that he favors turning them over to "private financial interests." 19 It would be a great surprise, indeed, if they should be turned over to any private interests independent of the supranational system here described, especially since the Railways bonds are held by the British South Africa Company and the major users of the power from Kariba are the mining companies.

All the evidence that is in, so far, supports our hypothesis that as political empires dissolve, states become weaker relative to the supranational mining system.

One should take into account, finally, the current trend toward relaxation of trade barriers-for example, the common market in Europe, and American legislation to this effect in 1962. Directed primarily at increasing economic activity in general, the reductions in tariffs and in national-state controls of many kinds benefit especially those firms already organized internationally. The climate now provides legal sanction and popular support for their supranational integration, and they.

19 Kenneth Kaunda, in press conterence reported in Federation of Rbodesia and Nyasaland Newsletter, January 25, 1963. 
more than "local" firms, are in a position to adapt to the widening markets provided. "Gross national product" had already been illusory insofar as such productive units as those engaged in the African mineral industry were concerned. The corporations of this group are registered in many different states, and are owned and directed by persons of diverse nationalities. ${ }^{20}$ Where one or another is registered, or where one or another director is citizen, has little to do with economic facts, to which legalisms often bow. The Société Générale de Belgique, during World War II, had directors resident in both Axis and Allied territories without, apparently, any disruption of their operations. That South Africa's withdrawal from the Commonwealth involved no change in her trade and financial arrangements with the United Kingdom is also a case in point. Similarly, the politically inspired resolutions of the United Nations General Assembly calling for trade boycott of South Africa has virtually no economic consequences. The supranational integration in the economic sphere tends more and more to supersede the political, international, ties or cleavages. Nations are, in a very real sense, becoming more interdependent. The concept of "national economy" may be an illusion which must be given up if we are to understand the new world of industrial systems.

20 The first 107 companies on which I collected data of this kind were registered as follows: 49 in South Africa, 16 in Northern Rhodesia, 9 in the United Kingdom, 7 in Belgium, 7 in Congo, 7 in the United States, 5 in Southern Rhodesia, 3 in Portugal, 3 in Canada, 1 in Tanganyika. These proportions should not be overemphasized, however, since the system does not have definite limits, and the observer could bias the sample. One interesting observation, however, is that French companies seem poorly represented. Could this have anything to do with France's negative attitude toward Britain's entry into the Common Market?

\section{CONCLUSIONS}

The Tallensi of northern Ghana maintained a decentralized "political" system without sharp boundaries by symbolizing the "dimension" of people in one kind of leader (na'am-Chief of the Land's People) and the "dimen. sion" of land in another (tendaanaCustodian of the Earth ). ${ }^{21}$ While both have an interest in what Fortes calls "prospering the community," neither kind of leader can do so without the collaboration of the other. My observations of the operation of the mineral industry of southern Africa suggest that, at the level of socio-cultural integration we are now approaching in the West, at any rate, national states, with their territorial basis, represent the "dimension" of land and people, while corporations represent the "dimension" of capital which is not territorially based. While both have an interest in "prospering the community" neither can do it alone. In such a system national states and supranational corporations would interact on somëthing like an equal basis in a decentralized structure.

In order to understand the world that is rapidly becoming industrialized we ought to consider the changing ecological circumstances this industrialization entails. We ought, also, to open our minds to the possibility that cultural evolution may not have ended with the development of state institutions. If we organize our observations of recent history in the comparative perspective of anthropological theory we may discern some principles and structures, however incipient, of an emerging new and higher level of sociocultural integration. In this field anthropology has something to offer as well as something to learn.

"21 Meyer Fortes, "The Tallensi" in African Political Systems, edited by Meyer Fortes and E. E. Evans-Pritchard, London, 1940. 